\title{
Current situation in the research of teaching English grammar in Slovakia
}

\section{[Sucasny stav skumania vyucovania gramatiky anglickeho jazyka na Slovensku]}

\author{
Gabriela Lojova
}

\section{DOI: 10.18355/XL.2016.09.70-80}

\begin{abstract}
Anotácia
Článok poskytuje ucelený pohl'ad na problematiku vyučovania gramatiky anglického jazyka na Slovensku. Prezentuje, analyzuje a usúvzt'ažňuje výsledky výskumov realizovaných $\mathrm{v}$ našom edukačnom kontexte. Na pozadí Johnsonovho modelu učenia sa cudzieho jazyka načrtáva hlavné problémy pri rozvíjaní deklaratívnych i procedurálnych vedomostí. Teoreticky analyzuje ich možné príčiny v rovine lingvistickej, pedagogickej i intrapersonálnej. Podčiarkujúc nutnost' d’alšieho skúmania problematiky, poskytuje početné podnety pre následné teoretické analýzy a vedecké výskumy, ktorých výsledky by mali tvorit' východisko pre koncipovanie lingvodidaktických odporúčaní.
\end{abstract}

Kl’účové slová: Vyučovanie a učenie sa gramatiky angličtiny, výsledky výskumov, deklaratívne a procedurálne vedomosti, príčiny problémov

V súčasnom globalizujúcom sa svete čoraz viac stúpajú nároky na cudzojazyčnú komunikačnú kompetenciu, a to hlavne v anglickom jazyku (AJ), ktorý sa postupne stáva lingua franca. Pred odborníkmi sa tak sústavne vynárajú nové výzvy zacielené na zvyšovanie efektívnosti učenia sa a vyučovania cudzích jazykov (CJ). Do popredia vystupujú najrôznejšie problémy či už na úrovni všeobecných koncepčných otázok, fundamentálnych teoretických východísk, alebo konkrétnych metodických odporúčaní pre pedagogickú prax. V odbornej literatúre sa dlhodobo prezentujú početné vedecké diskusie a polemiky o zástoji gramatiky pri učení sa CJ a o adekvátnej pedagogickej intervencii.

V slovenskom edukačnom kontexte pri rozvíjaní cudzojazyčnej komunikačnej kompetencie neustále rezonuje problematika kvalitného rozvíjania jazykovej a pragmatickej subkompetencie pri učení sa AJ. Dlhodobé empirické skúsenosti, ako aj analýzy procesu a výsledkov výučby ukazujú, že cudzojazyčná performancia študentov $\mathrm{v}$ reálnej produkcii nie je dostatočne konzistentná $\mathrm{s}$ ich mentálnymi reprezentáciami systému ciel'ového jazyka ani s ich performanciou $\mathrm{v}$ metajazykových úlohách. Uvedenej problematike sa už dlhšie obdobie venuje aj vedecko-výskumná činnost' na Katedre anglického jazyka a literatúry PdF UK (KAJL) prostredníctvom viacerých vzájomne prepojených projektov. Hlavným ciel'om týchto aktivít je skoncipovat' teoretický rámec ako východisko pre systematické riešenie tejto problematiky, na jeho základe navrhnút' smerovanie $\mathrm{v}$ lingvodidaktických odporúčaniach a v súlade s nimi vypracovat' konkrétne aplikačné odporúčania a metodické materiály. Východiskom nosnej teoretickej analýzy problematiky sú výsledky viacerých samostatných výskumov zameraných hlavne na mapovanie aktuálneho stavu vo vyučovaní AJ na Slovensku, ako aj výsledky experimentálneho overovania prvotne navrhnutých metodických postupov. Obzvlášt' dôležitú súčast' teoretického bádania tvorí analýza príčin skúmaných problémových aspektov a náčrt možných riešení, ktoré je následne nutné d’alej rozpracovávat'

XLinguae Journal, Volume 9 Issue 3, June 2016, ISSN 1337-8384 
a experimentálne overovat'.

Úvodná teoretická analýza problematiky vyučovania gramatiky AJ v našich podmienkach je podrobne spracovaná v publikáciách G. Lojovej $(2001,2004)$. Následne bola doplnená o d’alšie relevantné aspekty vo vedeckej monografii G. Lojovej a kol. (2015), ktorá, opierajúc sa o súčasný stav vedeckého poznania vo svete i u nás, poskytuje relatívne ucelený súbor teoretických východísk rešpektujúcich sociokultúrny, jazykový a edukačný kontext na Slovensku. Zahŕňa pritom všetky relevantné oblasti, počínajúc od lingvistických teórií a definícií jazyka cez psychologické teórie učenia sa, teórie a modely osvojovania si druhého jazyka až po lingvodidaktiku zameranú na postavenie gramatiky v rôznych prístupoch a metódach. $\mathrm{Na}$ pozadí existujúcich rôznorodých teoretických prístupov je pri riešení tejto problematiky nutné dôsledne rozlišovat' medzi procesmi osvojovania si druhého jazyka a učenia sa cudzieho jazyka. Charakteristiky týchto odlišných procesov sú predmetom relatívne zložitých kognitívnopsychologických, neuropsychologických a neurolingvistických analýz (Fabbro, 1999; Krashen, 2013; Paradis, 2004, 2009; Schumann et al., 2004; Skehan, 1998; Ullman, 2001 a iní). Avšak z pedagogickopsychologického hl'adiska možno považovat' za podstatné to, ako samotný učiaci sa jedinec vníma ciel’ový jazyk: či ako prirodzený prostriedok komunikácie, ktorý si podvedome osvojuje vo svojom bežnom prostredí a ktorý mu umožňuje hladkú socializáciu, alebo len ako predmet $\mathrm{v}$ škole, pričom mu zmysel jeho učenia sa nezriedka uniká. Toto principiálne odlišné subjektívne vnímanie CJ stimuluje odlišné mechanizmy učenia sa a afektívne premenné, hlavne motivačné, ktoré možno považovat' za obzvlášt' dôležité. Nedostatočné rozlišovanie medzi podstatou týchto procesov vedie kneadekvátnemu zovšeobecňovaniu či transferu poznatkov a skúseností, zčoho rezultuje používanie neefektívnych, neraz dokonca kontraproduktívnych vyučovacích prístupov.

$\mathrm{Aj}$ napriek výraznej pluralite názorov odborníkov za najvhodnejší model vyučovania $\mathrm{AJ}$ na Slovensku v súčasnosti možno po dôkladnom prehodnotení teoretických východísk, ktoré nám súčasná veda poskytuje, považovat' Johnsonov model učenia sa jazyka ako rozvíjania zručností (Johnson 1996). Adaptácia tohto modelu na podmienky nášho edukačného, jazykového a sociokultúrneho kontextu, jeho konkretizácia pri vyučovaní gramatiky a zdôvodnenie jeho vhodnosti bolo podrobne rozpracované v publikácii G. Lojovej (2004).

\section{Výskum vyučovania gramatiky AJ}

Tradičné prístupy pri vyučovaní AJ, ktoré, ako sa ukazuje, na Slovensku stále dominujú, sa z hl'adiska Johnsonovho modelu a definovania jeho základných pojmov (deklaratívne a procedurálne vedomosti, automatizácia, proceduralizácia a dolad’ovanie) premietajú do neúmerného preceňovania deklaratívnych vedomostí na úkor procedurálnych. Dominuje teda dôraz na učenie sa teoretických gramatických pravidiel na úkor rozvíjania kompetencií a zručností používat' tieto pravidlá plynulo, správne a sebaisto $\mathrm{v}$ reálnej komunikácii. Uvedená hypotéza o dominancii tradičného vyučovania $\mathrm{AJ}$ súčasne implikuje aj nedostatočnú aplikáciu komunikatívneho prístupu v súčinnosti s prístupom zameraným na žiaka. Bola vytvorená na základe dlhodobých empirických skúseností z rôznych stupňov a typov vzdelávania, spätnej väzby od samotných žiakov, ako aj na základe výsledkov rôznych analytických štúdií a štatistických dokumentov (napríklad prieskumu vedomostí maturantov „Monitor“ a pod.). V odbornej verejnosti bola vnímaná ako fakt, hoci nebola podložená výsledkami výskumov. Práve na overenie tejto hypotézy sa zameralo niekol'ko na seba nadväzujúcich výskumov realizovaných na KAJL PdF UK.

Prvý výskum prebiehal v roku 2000. Podrobný popis teoretických východísk, metodológie výskumu a analýza výsledkov sú uvedené v publikácii G. Lojovej (2001). Ciel'om tohto relatívne rozsiahleho výskumu bolo zmapovat' a porovnat' 
názory a postoje učitel'ov a žiakov na vyučovanie gramatiky AJ so zretel'om na zástoj rozvíjania deklaratívnych a procedurálnych vedomostí, ako aj na využívané metodické postupy. Vo výskume bola použitá metóda dotazníka. Jeho vnútorná konzistencia, overená koeficientom Cronbachova alfa, reflektuje dostatočnú reliabilitu použitého neštandardizovaného nástroja. Použitý bol Kolmogorovov - Smirnovov test. Výskumnú vzorku tvorilo 1127 respondentov, a to 1056 žiakov 3. a 4. ročníka zo 16 gymnázií v rôznych oblastiach Slovenska a ich 71 učitel'ov angličtiny. Štatistické metódy použité pri spracovávaní výsledkov umožnili vzájomné kvantitatívne porovnávanie odpovedí na jednotlivé položky, porovnávanie odpovedí na tú istú položku u žiakov a učitel'ov, ako aj zist'ovanie, či prípadné rozdiely ekvivalentných odpovedí sú náhodné alebo štatisticky signifikantné. $Z$ výsledkov výskumu uvádzame na tomto mieste stručnú analýzu a interpretáciu tých kvantitatívnych ukazovatel'ov, ktoré považujeme za relevantné z hl'adiska súčasnej situácie:

1. Podl'a názoru žiakov sa vo výučbe kladie výrazne väčší dôraz na rozvíjanie deklaratívnych vedomostí. V dôsledku toho žiaci nedokážu v reálnej komunikácii adekvátne používat' gramatické javy, ktoré teoreticky ovládajú. Potvrdzujú to výsledky v piatich položkách zo siedmich položiek dotazníka. Učitelia však prejavili opačný názor. V štyroch z uvedených položiek boli rozdiely medzi názormi žiakov a učitel'ov štatisticky signifikantné.

2. Ani žiaci, ani učitelia nepovažujú za potrebné znížit' rozsah deklaratívnych poznatkov. Z analýzy odpovedí však vyplývajú odlišné dôvody pre tento zhodný názor. Zatial' čo učitelia vyjadrili presvedčenie, že všetky deklaratívne poznatky sú potrebné, žiaci považujú viaceré javy za irelevantné, avšak ich osvojovanie im z hl'adiska kognitívnej náročnosti nerobí problémy.

3. Žiaci jednoznačne deklarujú, že na vyučovaní sa aplikujú hlavne tradičné metódy a dôraz sa kladie na teoretické vedomosti. Komunikačné metódy sú podla nich využívané relatívne zriedkavo. Štatistické ukazovatele v jednotlivých položkách dosahovali najextrémnejšie hodnoty $\mathrm{v}$ celom výskume, čo svedčí o výraznej vyhranenosti tohto názoru. Učitelia naopak jednoznačne deklarujú používanie prevažne komunikačných metód. Túto zjavnú kontradikciu názorov žiakov a učitel'ov podčiarkujú aj vel'mi vysoko signifikantné rozdiely vo všetkých relevantných položkách.

4. Uvedené zistenia výrazne korešpondujú s výsledkami v otázkach zameraných na vyučovacie aktivity. Aj tu žiaci naliehavo zdôrazňujú požiadavku viac precvičovat' preberané javy $\mathrm{v}$ zaujímavých komunikačných aktivitách a nielen v stereotypných cvičeniach. Názory učitel'ov však nie sú jednoznačné, často si dokonca vzájomne protirečia. Pri porovnávaní výsledkov žiakov a učitel'ov sa zistil vel'mi vysoko signifikantný rozdiel v troch položkách zo štyroch.

5. Všetci respondenti sa st'ažujú na nedostatok času a príležitostí na proceduralizáciu. Žiaci však pocit’ujú tento nedostatok ovel’a výraznejšie.

6. Pri skúmaní vplyvu výučby gramatiky na celkový vzt’ah k učeniu sa AJ sa nevyskytli extrémnejšie názory či výraznejšie rozdiely. Respondenti sa zhodli aj $\mathrm{v}$ názore, že nedostatočný rozvoj procedurálnych vedomostí prispieva $\mathrm{k}$ vytváraniu vnútorných bariér pri komunikácii vAJ.

7. Signifikantný rozdiel v odpovediach na otázky, čo robí žiakom najväčšie problémy, naznačuje, že podl'a učitel’ov správne použivanie gramatiky v komunikácii robí žiakom väčšie problémy, ako si oni sami uvedomujú. Žiaci však takmer jednoznačne deklarujú, že najväčšie problémy im robí chápat' štrukturálno-funkčné charakteristiky jazyka a hlavne rozdiely v použivaní podobných gramatických štruktúr.

Na základe analýzy výsledkov výskumu možno súhrnne konštatovat', že tak učitelia, ako aj žiaci pocit'ovali potrebu zefektívňovat' výučbu gramatiky AJ. Avšak

XLinguae Journal, Volume 9 Issue 3, June 2016, ISSN 1337-8384 
žiaci vyjadrovali túto potrebu takmer vo všetkých položkách naliehavejšie. Svojimi názormi jednoznačne potvrdili preceňovanie deklaratívnych vedomostí a neefektívne stereotypné precvičovanie. Naliehavo sa dožadovali moderných komunikačných metód, umožňujúcich efektívnejšiu proceduralizáciu. Podrobná analýza výsledkov tohto výskumu poskytuje množstvo podnetov na d’alšie skúmanie rôznych aspektov vyučovania AJ, ako aj na teoretickú analýzu príčin problémov.

Uvádzané zistenia potvrdila aj R. Rafajlovicova (2000) výskumom, ktorého výsledky nasvedčujú, že aj ked' sa u nás deklaruje komunikačný prístup k vyučovaniu AJ, pri testovaní gramatických vedomostí žiaci dosiahli najlepšie výsledky $\mathrm{v}$ dekontextualizovaných testoch a v testoch zameraných na metajazykovú uvedomelost' a nie v testoch, kde je použitie gramatickej štruktúry determinované kontextom.

V nadväznosti na uvedený výskum G. Lojovej T. Hlava v roku 2012 zopakoval rovnaký výskum na vzorke pozostávajúcej z 594 žiakov a 55 učitel’ov gymnázií. Podrobná analýza a interpretácia výsledkov výskumu je uvedená v jeho publikácii (Hlava, 2012). Podstatnou výskumnou otázkou bolo, či možno na základe názorov žiakov a učitel'ov konštatovat' zvýšenie kvality vo výučbe gramatiky AJ za uplynulých 12 rokov. Podrobná komparatívna analýza výsledkov obidvoch uvedených výskumov je prezentovaná v publikácii G. Lojovej a kol. (2015, kapitola 4). Vo všeobecnosti možno konštatovat', že aj ked' niektoré čiastkové výsledky naznačujú určitý posun, nepreukázali sa signifikantné rozdiely ani $\mathrm{v}$ názoroch žiakov, ani $\mathrm{v}$ názoroch učitel'ov $\mathrm{v}$ prospech väčšieho dôrazu na rozvíjanie procedurálnych vedomostí. Výsledky komparatívnej analýzy opät' jednoznačne poukazujú na skutočnost', že dominantnú pozíciu vo výučbe gramatiky AJ stále zaujímajú deklaratívne vedomosti. Žiaci identifikovali problém jasne a konzistentne prostredníctvom všetkých častí dotazníka. Názory učitel'ov boli menej extrémne, často aj nevyhranené, prípadne si jednotliví učitelia protirečili. Žiaci vo všeobecnosti nemajú problém s naučením sa gramatických pravidiel, no v porovnaní s pôvodným výskumom v roku 2013 vyjadrili svoje názory týkajúce sa irelevantnosti obsahu, ako aj neadekvátneho dôrazu na verbalizáciu gramatických pravidiel omnoho extrémnejšie. V praktickej rovine sa to odzrkadl'uje vo vysokej úrovni teoretických vedomostí žiakov, avšak ich schopnost' aplikovat' tieto vedomosti v rámci generatívne produkovaného rečového prejavu výrazne zaostáva. Pozitívnym sa zdá byt' fakt, že učitelia sú si tohto stavu vedomí. Názory učitel'ov na úroveň rozvoja procedurálnych vedomostí u žiakov sú však dost' kontroverzné. Celkove pri tom dominuje názor, že žiaci sú schopní gramaticky správne komunikovat' automaticky, t. j. bez vedomého monitorovania vlastnej produkcie, avšak iba pri používaní jednoduchých štruktúr. Pri zložitejších pravidlách nedochádza $\mathrm{k}$ dostatočnej proceduralizácii. Nedostatočne rozvíjaná komunikačná kompetencia a nesplnené očakávania žiakov navyše vedú $\mathrm{k}$ demotivácii a posilňovaniu nežiaducich postojov $\mathrm{k}$ vyučovaniu AJ.

Rovnaký výskum zopakovala v roku 2013 D. Blight aj v terciárnom vzdelávaní, a to $\mathrm{s} 1011$ študentmi vysokých škôl. Aj výsledky tohto výskumu boli vel'mi podobné. Ich podrobná analýza je uvedená v publikácii G. Lojovej a kol. (2015, kapitola 5). Opät’ jednoznačne potvrdzujú výraznú mieru využívania tradičných vyučovacích metód a dôraz na metajazykovú uvedomelost' na úkor rozvíjania produktívnych jazykových kompetencií. Silná potreba viac proceduralizovat' prebrané javy v zaujímavých a prirodzených komunikačných aktivitách rezonovala $\mathrm{v}$ odpovediach vo všetkých relevantných položkách.

Nedostatočné automatizovanie a dolad'ovanie naučených gramatických štruktúr potvrdil aj výskum, ktorý realizovala K. Hankerova v roku 2012 v primárnom vzdelávaní (Hankerova, 2014). Ciel’om jej výskumu bolo zmapovat', akým spôsobom učitelia vedú žiakov k vytváraniu základov gramatickej kompetencie z hl'adiska zameriavania sa na deklaratívne a procedurálne vedomosti. Výskumné hypotézy boli 
testované prostredníctvom dotazníka pre učitel'ov, ktorý využíval intervalovú a Likertovu škálu. Vypočítaná Cronbachova alfa potvrdila dostatočnú reliabilitu a homogenitu jednotlivých blokov dotazníka. V prípravnej fáze sa uskutočnil predvýskum s 133 respondentmi. Následnú výskumnú vzorku tvorilo 304 učitel’ov AJ v primárnom vzdelávaní z celého Slovenska. Výsledky výskumu možno stručne zhrnút' nasledovne:

1. Nepotvrdila sa hypotéza, že učitelia v primárnom vzdelávaní využívajú viac explicitnú formu výučby gramatiky ako implicitnú.

2. Podl'a výpovedí učitel'ov na vyučovaní zriedkakedy vyžadujú od žiakov, aby memorovali gramatické pravidlá. Vedú ich skôr $\mathrm{k}$ tomu, aby ich používali $\mathrm{v}$ komunikácii, a to prostredníctvom komunikačných aktivít.

3. Učitelia využívajú $\mathrm{v}$ prevládajúcej miere učebnicu a pracovný zošit a len málo priestoru sa dostáva modifikovaným úlohám $\mathrm{z}$ učebnice, materiálom a cvičeniam vytvoreným učitel’om či materiálom, ktoré si žiaci sami prinesú alebo vytvoria.

4. Učitelia využívajú personalizáciu na hodinách len obmedzene.

5. Učitelia sa viac sústred’ujú na precvičovanie izolovaných gramatických javov ako na ich používanie v kontexte, zamerané na postupnú proceduralizáciu všetkých preberaných gramatických javov.

Možno však predpokladat', že tieto údaje získané formou dotazníka sú do vel'kej miery skreslené vysokou subjektivitou výpovedí učitel'ov o svojom vlastnom pôsobení a tendenciou odpovedat' očakávaným (správnym) spôsobom alebo stredovou hodnotou. Pre zvýšenie validity získaných údajov by bolo potrebné doplnit' výskum pozorovaním a analýzou vyučovacích hodín a porovnat' výpovede učitel'ov s ich reálnou výučbou. Avšak vzhl'adom na ciel' výskumu možno nadobudnuté dáta považovat' za postačujúce. Získané údaje slúžili hlavne ako východisko pre koncipovanie metodických odporúčaní a zostavenie súboru doplnkových vyučovacích aktivít zameraných na proceduralizáciu gramatického učiva a aplikáciu princípov prístupu zameraného na žiaka (Hankerova, 2015). Pri ich koncipovaní bolo dôležité práve zistenie, že personalizáciu a zameranie na upevňovanie, automatizovanie a dolad'ovanie naučenej gramatiky využívajú učitelia len v obmedzenej miere. Nie sú teda dominantným prvkom výučby, ako to odporúča súčasné smerovanie $\mathrm{v}$ lingvodidaktike. Vytvorené metodické materiály boli čiastočne overované $\mathrm{v}$ experimentálnej výučbe. Toto overovanie v súčasnosti nad’alej pokračuje a odporúčané vyučovacie aktivity sa priebežne modifikujú.

Dôraz na personalizáciu, implicitne obsiahnutý v tomto výskume i v následných metodických odporúčaniach, je určitým nadviazaním na predchádzajúci výskum na KAJL PdF UK. Jeho hlavným ciel'om bolo teoreticky rozpracovat' problematiku využívania personalizácie ako nevyhnutného prostriedku efektívnejšieho rozvíjania cudzojazyčnej kompetencie žiakov. Následná pedagogicko-psychologická analýza problematiky bola doplnená metodickými pokynmi a konkrétnymi odporúčaniami pre prax (Lojova, Farkasova a Pcolinska, 2011).

Na otázky vplyvu preceňovania deklaratívnych vedomostí na plynulost' rečového prejavu sa zameral T. Hlava (Hlava, 2015). Vo svojom výskume realizovanom v roku 2014 vychádzal z predpokladu, že efektívnost' učenia sa CJ sa prejavuje v kvalite rôznorodých aspektov mechanizmu tvorby reči, pričom jedným z podstatných ukazovatel'ov je práve plynulost' ústneho prehovoru. Teoreticky vychádzal z koncepcie Kormosovej (2009), podl'a ktorej pamät'ový sklad pre informácie o CJ robí dištinkciu deklaratívnych a procedurálnych vedomostí relevantnou, pretože informácie v ňom obsiahnuté majú deklaratívny charakter. Žiaci teda disponujú vedomost'ami, ako pomocou gramatických pravidiel vytvárat' významy. Tieto

XLinguae Journal, Volume 9 Issue 3, June 2016, ISSN 1337-8384 
vedomosti sa však nevyužívajú pri zautomatizovaných procesoch tvorby ústneho prejavu, ktoré zabezpečujú jeho plynulost' a ako vstup využívajú práve procedurálne lingvistické vedomosti. Ciel'om tohto Hlavovho výskumu bolo opät' zmapovat' proporcionalitu zamerania sa na deklaratívne a procedurálne vedomosti vo vyučovaní AJ vo vyššom sekundárnom vzdelávaní a následne zistit', do akej miery takéto odlišné zameranie ovplyvňuje plynulost' ústneho prejavu v AJ. Výskumný súbor pozostával z 93 študentov a ich 9 učitel’ov z 3 gymnázií. V tomto metodologicky relatívne náročnom výskume bolo podrobne spracované široké spektrum rôznorodých údajov, ktoré boli následne usúvzt’ažnené. Použité boli viaceré metódy vedeckého výskumu:

1. audiozáznamy ústneho prejavu žiakov, slúžiace ako podklad pre kvantifikáciu ich ústneho prejavu prostredníctvom pauzológie, prepísané do textového editora vrátane netichých páuz (,eeh“), slov s charakterom netichej pauzy (,,aaand“, „becaaause"), autokorekcií, reformulácií, repetícií a falošných štartov;

2. audiozáznamy vyučovacích hodín $\mathrm{v}$ rozsahu 4 týždňov, pričom sledovanými ciel'ovými informáciami boli:

- realizácia a proporcia sekvencie deklaratívna prezentácia - koncentrované precvičovanie - proceduralizácia,

- zmysluplné a produktívne aktivity,

- $\quad$ stupňovanie náročnosti úloh a odklon od zamerania na formu.

Jednotlivé nahrávky boli spracované programom AUDACITY, ktorý umožňuje strihat' zvolený audiosúbor a vytvárat' rôzne nezávislé vrstvy. Takto bolo možné vytvorit' určitý model na základe času stráveného rozprávaním, resp. disponovaním mocou udelit' žiakom priestor na ústny prejav;

3. metóda pauzológie, umožňujúca kvantifikovat' ústny prejav podl’a štandardne používaných kritérií, vd'aka čomu bolo možné porovnávat' výkony žiakov v rôznych skupinách.

Výsledky výskumu jednoznačne poukázali na skutočnost', že medzi skupinami žiakov, ktorých výučba sa odlišovala $\mathrm{v}$ miere pozornosti venovanej rozvíjaniu deklaratívnych a procedurálnych vedomostí, existovali štatisticky signifikantné rozdiely $\mathrm{v}$ dosahovanej úrovni plynulosti ústneho prejavu. V závislosti od stúpajúcej dominancie zamerania sa na deklaratívne vedomosti klesala plynulost' prehovoru žiakov vo všetkých kritériách okrem priemernej dížky uskutočnených páuz. Naopak, pri zvýšenom dôraze na rozvíjanie procedurálnych vedomostí sa $\mathrm{v}$ ústnom prejave žiakov vyskytoval menší počet páuz, dlhšie slovné ret’azce medzi pauzami, väčší celkový rozsah prehovoru a nižšia miera disfluencií v podobe repetícií a falošných štartov. Výsledky tohto výskumu teda potvrdili hypotézu, že preceňovanie deklaratívnych vedomostí znižuje fluenciu ústneho prejavu. Pre komplexnost' záverov by však bolo potrebné v d'alších výskumoch súčasne merat' aj správnost' prehovoru, aby sa zistilo, či sa zvýšená fluencia nepremieta do znižovania gramatickej správnosti, respektíve zrozumitel'nosti komunikovaného obsahu. Dominanciu tradičného vyučovania potvrdila v uvedenom výskume aj skutočnost', že výrazné zameranie na rozvíjanie procedurálnych vedomostí bolo pozorované iba u dvoch učitel'ov a čiastočná dominancia $\mathrm{u}$ troch $\mathrm{z}$ deviatich. Žiaci týchto učitel'ov vykazovali signifikantne vyššiu úroveň fluencie. Vzhl’adom na relatívne malú vzorku a časové obmedzenie výskumu jeho závery nie je možné generalizovat', no aj napriek tomu ho možno považovat' za významný prínos v skúmaní uvedenej problematiky.

Výsledky predstavených výskumov jednoznačne potvrdili hypotézy vytvorené na základe empirických skúseností, že v našom edukačnom prostredí aj napriek snahe odborníkov poskytovat' učitel'om metodické usmerňovanie opierajúce sa o najnovšie poznatky lingvodidaktiky (Danova, 2008; Homolova, 2006; Lencova a Danova, 2010; Strakova, 2005 a iné) stále dominujú tradičné prístupy $\mathrm{k}$ výučbe $\mathrm{CJ}$, hoci ich efektívnost' nemožno považovat' za dostatočnú. 


\section{Súčasné smerovanie vo výskume}

Podrobná analýza výsledkov uvádzaných výskumov nasvedčuje, že pri výučbe AJ pretrváva neúmerný dôraz na poznanie a verbalizáciu gramatických pravidiel a na ich precvičovanie v dekontextualizovaných cvičeniach. Žiakom sa neposkytuje potrebný priestor na rozvíjanie praktických komunikačných kompetencií prostredníctvom produktívnych úloh a autentickej (resp. kváziautentickej) a zmysluplnej komunikácie. V duchu Johnsonovho modelu tak dochádza k nedostatočnej proceduralizácii, t. j. k automatizovaniu správneho používania naučených štrukturálnych javov vo variabilných kontextoch a k dolad'ovaniu chápania štrukturálno-funkčných charakteristík jazyka. Vo všeobecnejšej rovine sa to premieta do celkového preceňovania gramatickej správnosti na úkor rozvíjania sebaistej a fluentnej produkcie. Dôsledkom takéhoto vyučovacieho prístupu je disproporcia medzi úrovňou mentálnych reprezentácií systému ciel'ového jazyka, výkonom v metajazykových úlohách a úrovňou cudzojazyčnej performancie v reálnej komunikácii. Navyše má negatívny dosah na d’alšie aspekty učenia sa AJ: vplýva predovšetkým na rýchle zabúdanie lingvistických vedomostí, vytváranie komunikačných bariér či brzdenie plynulosti prehovoru. Problematika vytvárania komunikačných bariér a nedostatočnej sebaistoty pri učení sa CJ je relatívne zložitá a determinovaná aj mnohými d'alšími faktormi. Ked’že ju u nás možno považovat' za obzvlášt' aktuálnu, v budúcnosti by bolo potrebné zamerat' na ňu výskumnú pozornost'. Poznatky o zákonitostiach fungovania pamäte a možnostiach redukovat' zabúdanie, ktoré nám poskytuje kognitívna psychológia, boli pre potreby učitel'ov čiastočne adaptované aj na proces učenia sa CJ a spracované v publikácii G. Lojovej, E. Farkasovej a A. Pcolinskej (2011) a G. Lojovej a Z. Strakovej (2012). Autorky v nich však načrtávajú aj množstvo otázok, ktoré by bolo potrebné vedecky skúmat'. $\mathrm{Na}$ otázky disproporcií medzi úrovňou mentálnych reprezentácií systému cielového jazyka, výkonom v metajazykových úlohách a výkonom v produktívnych a komunikačných úlohách je zameraný plánovaný výskum na KAJL PdFUK, ktorý by sa mal realizovat' v rokoch $2017-2019$.

\section{Analýza príčin nedostatočného rozvíjania gramatickej kompetencie}

Pri riešení problematiky nedostatočného rozvíjania gramatickej kompetencie je nutné $\mathrm{v}$ prvom rade analyzovat' možné príčiny tohto dlhodobo pretrvávajúceho slabého článku výučby AJ. V počiatkoch skúmania tejto problematiky sa hlavná pozornost' zameriavala na podceňovanú proceduralizáciu ako hlavnú príčinu nedostatočne rozvíjanej komunikačnej kompetencie. Počiatočná teoretická analýza mechanizmov a procesu proceduralizácie a aplikačné odporúčania na úrovni pedagogicko-psychologických princípov sú pomerne podrobne rozpracované v publikácii G. Lojovej (2004). Hlavné problémy vyplývajú zo samotnej podstaty tohto procesu. Proceduralizácia totiž na rozdiel od naučenia sa deklaratívnych vedomostí neprebieha jednorázovo. Je to dlhodobý plynulý proces postupnej automatizácie a dolad’ovania štrukturálno-funkčných charakteristík jazyka. Pritom automatizovanie zložitejších gramatických štruktúr je podmienené zautomatizovaním ich komponentov na úrovni nižších zručností, čo si vyžaduje cyklické koncipovanie gramatického obsahu. Podstatnú úlohu tu logicky zohráva aj didaktická následnost' gramatických javov. Vychádzat' by mala $\mathrm{v}$ prvom rade z poznatkov o zákonitostiach vývinu interjazyka, ktoré však na Slovensku doposial' neboli skúmané. Navyše pri akomkol'vek používaní ciel’ového jazyka súčasne prebieha proceduralizácia viacerých štrukturálnych javov s odlišným stupňom dosiahnutej automatizácie. Táto odlišnost' je determinovaná nielen dížkou a kvalitou doterajšej proceduralizácie, ale aj odlišnou kognitívnou náročnost'ou samotných štruktúr, pedagogickými podmienkami, ako aj

XLinguae Journal, Volume 9 Issue 3, June 2016, ISSN 1337-8384 
individuálnymi charakteristikami žiakov a interpersonálnymi rozdielmi. Vo výučbe sa to premieta predovšetkým do zložitej koordinácie vyučovacích aktivít a časovej náročnosti komunikačných a produktívnych úloh. Rovnako problémové sú otázky hodnotenia žiakov a posudzovania efektívnosti vyučovacích aktivít, ked’že výsledky proceduralizácie sa prejavia $\mathrm{v}$ relatívne dlhodobom horizonte. Pre zabezpečenie kvalitnej výučby by bolo potrebné, aby všetky uvádzané charakteristiky boli zakomponované do tvorby učebníc a metodických materiálov v podobe premysleného súboru navzájom nadväzujúcich vyučovacích aktivít vhodných na výučbu $\mathrm{AJ}$ v našom edukačnom prostredí.

$\mathrm{Na}$ čiastočné overenie predpokladu, že používanie premysleného súboru vyučovacích aktivít môže výrazne posilnit' proceduralizáciu, P. Hitkova v roku 2013 realizovala na vzorke dospelej populácie výskum zameraný na experimentálnu výučbu gramatiky AJ s použitím cielene zostaveného súboru učebných úloh, ktorý túto hypotézu potvrdil. Metodológia výskumu, prezentácia a analýza výsledkov je uvedená v publikácii G. Lojovej a kol. (2015, kapitola 6). Je zrejmé, že v budúcnosti by bolo potrebné realizovat' rovnako zameranú experimentálnu výučbu na všetkých stupňoch a typoch výučby AJ, ktorá by slúžila ako východisko pre systematické koncipovanie a priebežné aktualizovanie komplexných metodických materiálov.

Následné teoretické štúdie (Lojova a kol. 2015) predstavujú určitý úvod do skúmania často opomínaného faktu, že aj napriek prílišnému dôrazu na učenie sa gramatických pravidiel majú žiaci nezanedbatel’né problémy nielen pri ich správnom používaní, ale aj pri ich správnom chápaní. Okrem empirických skúseností to do určitej miery potvrdzujú aj výsledky uvádzaných výskumov. Ukazuje sa, že najväčšie problémy žiakom robí chápanie rozdielov a funkčných charakteristík podobných gramatických javov a štruktúr, ktorých funkcia je vo výraznej miere subjektívne alebo kontextovo determinovaná. Problém sa ešte výraznejšie prejavuje v situáciách, ked' je potrebné selektovat' $\mathrm{z}$ viacerých gramatických štruktúr, ktoré možno $\mathrm{v}$ danom kontexte použit', avšak každá $\mathrm{z}$ nich $\mathrm{v}$ rôznej miere modifikuje komunikovanú informáciu.

Pri výučbe gramatiky CJ je na deklaratívnom stupni Johnsonovho modelu ciel'om umožnit' žiakom konštruovat' si počiatočnú vnútornú reprezentáciu systému jazyka, ktorá tvorí východisko pre následnú proceduralizáciu. Kvalitná vnútorná reprezentácia je najpodstatnejšia prerekvizita pre efektívnu proceduralizáciu. Možno predpokladat', že pri učení sa gramatických deklaratívnych vedomostí problém nie je v pamätovom uložení databázy vo forme sémantických spojení, ale vo všeobecnom súbore interpretačných procedúr používaných na aplikáciu údajov z databázy vo variabilných kontextoch. Pri skúmaní potenciálnych príčin týchto problémov G. Lojova (Lojova a kol. 2015, kapitola 1) načrtáva viacero rovín problematiky, ako sú lingvistické faktory, charakteristiky učiacich sa jedincov či edukačné podmienky.

Pokial' ide o lingvistické či jazykové aspekty, za najvšeobecnejšie príčiny nedostatočného rozvíjania gramatickej kompetencie možno považovat' diverzitu prístupov rôznych lingvistických škôl a variabilitu analýz anglickej gramatiky, ktorá sa následne transformuje do pedagogických gramatík. Táto diverzita sa premieta do odlišného vysvetl'ovania toho istého javu v rôznych učebniciach. Najvýraznejšie sa to prejavuje práve pri interpretácii funkčných charakteristík jednotlivých štruktúr, ktorá je často výrazne subjektívne koncipovaná. Vedie to k neistote nielen u žiakov, ale nezriedka aj u samotných učitel'ov, ktorí podvedome očakávajú unifikované deklaratívne prezentovanie danej gramatickej štruktúry. Je to prirodzený dôsledok výraznej interferencie stratégií pri učení sa systému pravidiel slovenského jazyka, kde vysvetlenia akéhokol'vek gramatického javu v rôznych publikáciách sú konzistentné a v súlade so všeobecne záväznými kodifikovanými pravidlami spisovnej slovenčiny. Navyše tradičné vyučovanie slovenčiny vedie $\mathrm{k}$ memorovaniu a akumulovaniu pravidiel bez ich dostatočného kognitívneho spracovania. Žiaci podvedome aplikujú 
tieto stratégie aj pri učení sa anglickej gramatiky, hoci nie sú rovnako efektívne, ba dokonca môžu byt' aj kontraproduktívne, ked'že môžu obmedzovat' konštruovanie správnej vnútornej reprezentácie systému AJ. Navyše memorovanie rôznorodej pedagogickej deskripcie toho istého javu často vedie $\mathrm{k}$ redundantnej akumulácii definícií a pravidiel bez uvedomovania si, že obsah týchto odlišne formulovaných deskripcií je totožný. Vyvstáva tu otázka, ako tento problém riešit: či napríklad tvorbou národných učebníc, kde by bola prezentácia deklaratívnych poznatkov adekvátne unifikovaná a prispôsobená metajazykovej uvedomelosti slovenských žiakov, alebo rozvíjaním tolerancie nejednoznačnosti a flexibility $\mathrm{v}$ ich metajazykovom myslení.

Za d’alší relevantný lingvistický aspekt možno považovat' jeden zo základných rozdielov medzi slovenčinou, typickým syntetickým jazykom s bohatou flexiou a afixáciou a relatívne stabilnými a striktnými gramatickými pravidlami, a angličtinou, typickým analytickým, dynamicky sa meniacim jazykom s výrazne flexibilnejšími pravidlami. Štrukturálno-funkčné charakteristiky jazyka v slovenčine sú teda dominantne určované jazykovými pravidlami na rozdiel od angličtiny, kde sú vo výrazne väčšej miere determinované kontextom (jazykovým alebo situačným) alebo subjektívne podmienené. Efektívne učenie sa takýchto pravidiel si opät' vyžaduje zvýšenú mieru tolerancie nejednoznačnosti a flexibility v metajazykovom myslení. A práve tieto charakteristiky môžu byt' u našich žiakov nedostatočne rozvinuté, v dôsledku čoho si t’ažko zvnútorňujú fakty, ktoré nezapadajú do ich kognitívnej organizácie. Prežívajú pritom pocit neistoty, chaosu a určitej kognitívnej či afektívnej frustrácie. V týchto súvislostiach sa opät' vynára otázka, ako pri výučbe AJ rozvíjat' metajazykovú flexibilitu a kontextové myslenie žiakov.

Z pedagogického hl'adiska možno za jeden z hlavných problémov nedostatočného rozvíjania gramatickej kompetencie považovat' práve dominujúce tradičné vyučovacie prístupy. V počiatkoch učenia sa angličtiny si žiaci vdôsledku nedostatočnej proceduralizácie nevytvoria kvalitnú vnútornú reprezentáciu základov systému angličtiny. Následné dopíňanie nadväzujúcich poznatkov, ktoré by malo postupne viest' ku konštruovaniu uceleného systému vzájomne poprepájaných štrukturálnofunkčných charakteristík jazyka, môže viest' $\mathrm{k}$ chaosu. Navyše nedostatočné zameranie sa na proceduralizáciu a dolad’ovanie podstatne ovplyvňuje aj kvalitu deklaratívnej reprezentácie, ktorá nevzniká jednorázovo. Pre správne pochopenie interpretačných procedúr na aplikáciu štrukturálnych pravidiel je podstatný práve proces dolad'ovania. Prvotne konštruovaná deklaratívna reprezentácia je do rôznej miery subjektívne skreslená a postupne sa koriguje, čím dochádza k zvnútorňovaniu konfigurácie možných funkcií naučených gramatických štruktúr. Ak však nedochádza $\mathrm{k}$ dostatočnej proceduralizácii, ani deklaratívna reprezentácia nemôže byt' kvalitná. Naopak, ked' je deklaratívna reprezentácia nedostatočná, proceduralizácia nemôže prebiehat' efektívne.

Rozsiahla škála príčin uvedeného stavu bezpochyby súvisí $\mathrm{s}$ edukačnými podmienkami, a to $\mathrm{s}$ nedostatočným aplikovaním princípov prístupu zameraného na žiaka, s rôznorodost'ou učebníc, postavením gramatického obsahu v nich či s absenciou komparatívneho hl'adiska, s rešpektovaním individuálnych osobitostí žiakov, ako aj s rôznymi aspektmi osobnosti samotného učitel'a, ktoré v podstatnej miere ovplyvňujú výslednú efektívnost' učenia sa gramatiky AJ u žiakov. Prvotný náčrt analýzy týchto vplyvov, ktorý možno považovat' aj za výzvu pre odborníkov a podnet pre d’alšie výskumné zameranie, je uvedený v publikácii Deklaratívne a procedurálne vedomosti vo vyučovaní anglického jazyka (Lojova a kol., 2015) 


\section{Záver}

Ako je zrejmé, predstavená problematika je zložitejšia, ako sa na prvý pohl’ad javí. Hoci okrem bohatých empirických skúseností máme už aj na Slovensku k dispozícii niekol'ko teoretických analýz a výsledkov výskumov, stále je pred odborníkmi množstvo otázok a problémov, na ktoré by bolo potrebné zamerat' výskumnú pozornost'. A to nielen v samotnej lingvodidaktike, ale aj v d'alších vedných oblastiach, ktoré majú potenciál vniest' viac svetla do zložitého procesu učenia sa a vyučovania cudzích jazykov. Práve premost'ovanie relevantných vedeckých disciplín a aplikovanie poznatkov z neurolingvistiky, psycholingvistiky, pragmalingvistiky, kognitívnej psychológie, komparatívnej lingvistiky a iných disciplín do konkrétneho procesu rozvíjania gramatickej kompetencie pri učení sa CJ v našom jazykovom, sociokultúrnom a edukačnom kontexte by bezpochyby urýchlilo napredovanie $v$ tejto oblasti. Štúdia poskytuje množstvo podnetov na d'alšie smerovanie teoretických analýz skúmanej problematiky, ako aj na realizáciu výskumov, ktorých výsledky by mohli slúžit' ako východisko, z ktorého bude možné vychádzat' pri koncipovaní lingvodidaktických princípov a odporúčaní pre vyučovaciu prax, ako aj pri skvalitňovaní vzdelávania učitel'ov.

\section{Literatúra}

DANOVA, M. 2008.Vybrane aspekty prace s gramatikou vo vyucbe cudzich jazykov. Banska Bystrica: UMB. ISBN 978-80-80836-30-6.

FABBRO, F. 1999. The Neurolinguistics of Bilingualism: An Introduction. UK: Psychology Press Ltd, Publishers. ISBN 978-0863777554.

HANKEROVA, K. 2014. Proceduralization and teaching of English in Slovak primary education. In: Jazykovedne, literarnovedne a didakticke kolokvium XXIV. Bratislava: Z-F Lingua, pp. 39-53. ISBN 978-80-89328-96-3.

HANKEROVA, K. 2015. Anglicka gramatika putavo a komunikativne. Bratislava: ZF LINGUA. ISBN 978-80-8177-014-2.

HOMOLOVA, E. 2006. Teaching and Learning Grammar. In: Teoria a prax pripravy ucitelov anglickeho jazyka. Banska Bystrica: FHV UMB, pp. 7-11. ISBN 978-808083-297-8.

HLAVA, T. 2012. Increasing the efficiency of teaching English grammar in secondary education. (diplomova praca), Bratislava: UK.

HLAVA T. 2015. Dimenzia vyucovania gramatiky: rozvijanie plynulosti ustneho prejavu. BA: Z-F Lingua. ISBN 978-80-8177-013-5.

JOHNSON, K. 1996. Language Teaching and Skill Learning. Oxford: Blackwell.

ISBN 0-631-16877-6.

KORMOS, J. 2009. Speech Production and Second Language Acquisition. NewYork: Routledge. ISBN 0-8058-5658-7.

KRASHEN, S. 2013. Second Language Acquisition.Theory, Applications, and some Conjectures. Cambridge: CUP. ISBN 978-1-107-92109-2.

LENCOVA, I. a DANOVA, M. 2010. Celostna pedagogika vo vyucbe cudzich jazykov. Banska Bystrica: Fakulta humanitnych vied Univerzita Mateja Bela. ISBN 978-80-5570054-0.

LOJOVA, G. 2001. Psychologicke aspekty ucenia sa a osvojovania gramatiky angličtiny ako cudzieho jazyka: Doktorandska dizertacna praca. Bratislava: Univerzita Komenského.

LOJOVA, G. 2004. Teoria a prax vyucovania gramatiky cudzich jazykov. Bratislava: Z-F Lingua. ISBN 978-80-89328-53-6.

LOJOVA, G. - FARKASOVA, E. - PCOLINSKA, A. 2011. Vyuzivanie personalizacie vo vyucovani anglickeho jazyka v primarnom vzdelavani. Bratislava: Z-LINGUA, ISBN978-80-89328-62-8.

LOJOVA, G. - STRAKOVA, Z. 2012. Teoreticke vychodiska vyucovania anglictiny 
v primarnom vzdelavani. Bratislava: Univerzita Komenskeho. ISBN 978-80-2233315-3.

LOJOVA, G. a kol. 2015. Deklarativne a proceduralne vedomosti vo vyucbe anglickeho jazyka. Bratislava: UK. ISBN 978-80-223-3754-0.

PARADIS, M. 2004. A neurolinguistic theory of bilingualism. Amsterdam: John Benjamins. ISBN 978-9-027-24126-9.

PARADIS, M. 2009. Declarative and Procedural Determinants of Second Languages. Amsterdam: John Benjamins. ISBN 978-9-0272-4176-4.

RAFAJLOVICOVA, R. 2000. Testing verb forms through discrete-point and openended tasks. Presov: Presovska univerzita. ISBN 80-8068-002-7.

SCHUMANN, J. H. et al. 2004.The Neurobiology of Learning. Perspectives From Second Language Acquisition. London: LEA. ISBN 0-8058-6141-6.

SKEHAN, P. 1998. A Cognitive Approach to Language Learning. Oxford: OUP.

ISBN 0-19-437217-0.

STRAKOVA, Z. 2005. Learning and teaching grammar. In: English is a key. Ružomberok: Catholic University, pp. 213-217. ISBN 80-8084-043-1.

ULLMAN, M. T. 2001. The Declarative/Procedural Model of Lexicon and Grammar. In: Journal of Psycholinguistic Research. vol. 30, n. 1, pp. 37-69. ISSN 00906905.

Words: 4854

Characters: $38130(21,18$ standard pages $)$

Doc.PhDr. Gabriela Lojova, PhD.

Comenius University in Bratislava

Faculty of Education

Racianska 59, 81334 Bratislava

Slovakia

lojova@fedu.uniba.sk 